\title{
Allelopathic Evidence in Brachiaria decumbens and its Potential to Invade the Brazilian Cerrados
}

\author{
Elizabeth Gorgone Barbosa $^{1}$, Vânia Regina Pivello ${ }^{1 *}$ and Sérgio Tadeu Meirelles ${ }^{1}$ \\ ${ }^{1}$ Departamento de Ecologia, Instituto de Biociências; Universidade de São Paulo; Rua do Matão, Travessa 14; \\ Cidade Universitária Armando de Salles Oliveira; vrpivel@ usp.br; 05508-900; São Paulo - SP - Brasil
}

\begin{abstract}
The aim of this study was to look for evidence of allelochemicals in B. decumbens, in parts of the plant from where they could easily be released to the environment. The germination inhibition of Phalaris canariensis, Lactuca sativa (standard species) and Melinis minutiflora, another invasive African grass, was tested using B. decumbens germinating seeds and aqueous leachates of the roots, green and senescent leaves, at 5, 10 and 20\% w/v. Both the germinating seeds and the aqueous leachates of $\mathrm{B}$. decumbens reduced the germination of the species tested; the effectiveness of the aqueous leachates increased according to concentration. Apparently, the competitive advantage of $\mathrm{B}$. decumbens in the cerrados could be amplified via allelopathy.
\end{abstract}

Keywords: allelopathy, cerrado, biological invasion, Brachiaria decumbens, Melinis minutiflora

\section{INTRODUCTION}

Biological invasion has been recognized worldwide as one of the worst environmental problems that lead to biodiversity loss (Vitousek et al., 1997; Wilcove et al., 1998; Pivello et al., 1999a; Mack et al., 2001). Invasive plant species combine a set of characteristics that enable them to outcompete the native species and dominate the invaded ecosystems. Some of these attributes are: vegetative and sexual reproduction, high productivity and high growth rates due to efficient photosynthetic processes and the effective use of nutrients, large production of easily dispersed seeds with high germination rates, short life cycles, and allelopathy (D'Antonio and Vitousek, 1992; Cronk and Fuller, 1995; Rejmánek and Richardson, 1996; Williamson, 1996; Kolar and
Lodge, 2001). Allelopathy, simply defined as "the release of phytotoxins by plants" (Bais et al., 2003) can enhance the competitive success of the plant invaders, since the release of these phytotoxins in the environment may affect the growth and life processes of other community species (Whittaker and Feeney, 1971; Rice, 1984; Ridenour and Callaway, 2001; Callaway, 2002). The Brazilian cerrado is recognized as the richest savanna in the world concerning plant species, and it integrates the list of global hot spots (Myers et al., 2000; Mittermeier et al., 2004). About 3,000 to 7,000 vascular plant species have been estimated for the cerrado sensu lato (following Coutinho's [1978] classification) (Castro et al., 1999) and more than 6,400 vascular species have been registered for the cerrado region (Mendonça et al., 1998), which includes more than 20

\footnotetext{
* Author for correspondence
} 
physiognomies of savanna, forest, and grassland (Ribeiro and Walter, 1998). However, the great biodiversity of the cerrado biome is being severely threatened by a number of invasive exotic species, namely the African grasses Brachiaria spp., Melinis minutiflora Beauv., Andropogon gayanus Kunth, Panicum maximum Jacq., Hyparrhenia rufa (Nees) Stapf., once brought to the country as cattle forage. These grasses have spread in such a magnitude that they occur in virtually every cerrado fragment, outcompeting native herbs (Klink, 1996a; 1996b; Pivello et al., 1999a; 1999b).

The high dominance of Brachiaria grasses over cerrado native herbs has recently raised investigations on the presence of phytotoxins in some species. In cerrados, B. decumbens (Nees) Stapf. has advanced massively throughout the native vegetation and formed monospecific patches with no other species growing below or close to it. In situ studies in São Paulo State cerrado areas have shown that even $M$. minutiflora, another East-African grass that invaded the cerrado, could have been displaced by B. decumbens (Pivello et al., 1999a; 1999b), revealing a high competitive advantage of the latter species.

The present study aimed at looking for evidence of allelopathy in Brachiaria decumbens through bioassays, and exploring parts of the plant from where the supposed allelopathic substances could be easily released to the environment: seeds, senescent and green leaves, and roots. The inhibition of seed germination of Lactuca sativa $\mathrm{L}$. cv Grand Rapids (Asteraceae) - a standard species for allelopathic tests -, Phalaris canariensis L. (Poaceae) - a (locally) non-invasive cultivated alien grass -, and of Melinis minutiflora Beauv. (Poaceae) - another grass invasive of cerrado was tested.

\section{MATERIALS AND METHODS}

\section{Plant material}

Brachiaria decumbens Stapf (Poaceae) is native to East Africa and was introduced in Brazil in the 1950 's thanks to its high palatability to cattle, productivity, and resistance (Kissmann, 1997).
The cultivar Basilisk, introduced in São Paulo State, exhibits perennial and vigorous plants, with rigid erect leaves that form tussocks about $1 \mathrm{~m}$ high. It adapted very well to the cerrado soils and climate and became a very infesting species.

Melinis minutiflora Beauv. (Poaceae) is also native to East Africa. It was probably accidentally introduced in Brazil in the XIX century (Parsons, 1972; Filgueiras, 1990) and lately became a cattle fodder species. It is also perennial and erect, and forms 0.4 to $1 \mathrm{~m}$ high tussocks (Lorenzi, 1991) but not as dense as those of $B$. decumbens. Melinis minutiflora was chosen for testing against $B$. decumbens because it also showed a great competitive ability over cerrado herbaceous species and together with $B$. decumbens, it represented one of the most threatening invasive plants in the bioma (Pivello et al., 1999a; 1999b).

Lactuca sativa L. cv. Grand Rapids (Asteraceae) is a standard species used in the tests of germination and allelopathy due to its high responsiveness and rapid germination (Ferreira and Aquila, 2000).

Phalaris canariensis L. (Poaceae) is a grass species not usually present in the cerrados but considered as an invader elsewhere in the world (ISI/TNC, 2005). Here, it was used as a Poaceae reference due to its high germination rates and availability.

The seeds of $B$. decumbens, $P$. canariensis and $L$. sativa were commercially acquired, whereas $M$. minutiflora seeds were field collected (July 2004).

\section{Plant extracts}

B. decumbens was cultivated in 8-1 plastic pots with commercial garden soil and maintained in a greenhouse at room temperature (around $28^{\circ} \mathrm{C}$ ), $50 \%$ relative humidity, and natural light intensity reaching $1000 \mu \mathrm{mol}$ maximum. Three months after the seeding, green leaves and roots were collected to make the extracts used in the tests. Senescent leaves were collected (September 2004) in the Cerrado Pé-de-Gigante Reserve (Vassununga State Park, SP).

Aqueous leachates of B. decumbens green leaves, senescent leaves and roots were prepared using $12.5,25$ and $50 \mathrm{~g}$ of the fresh material in $250 \mathrm{ml}$ of distilled water. The plant material was fitted into Erlenmeyer tubes and then shaken for $12 \mathrm{~h}$. The extracts were double filtered, resulting in 5, 10 and $20 \% \mathrm{w} / \mathrm{v}$ solutions, stored at $7^{\circ} \mathrm{C}$. 


\section{Tests}

The effects of the extracts and germinating seeds were tested adopting a full randomized design with six repetitions for each treatment and control groups. The seeds of $L$. sativa were allowed to germinate for three days while $P$. canariensis and M. minutiflora were allowed 10 days (following Brasil, 1992). To test for the allelopathic effects of $B$. decumbens germinating seeds, 30 of these and 30 seeds of the test species (M. minutiflora, $L$. sativa and $P$. canariensis) were put in Petri dishes (diameter $=11 \mathrm{~cm})$ with moistened filter paper and incubated in germination chambers at $26^{\circ} \mathrm{C}$, with $12 \mathrm{~h}$ light/darkness cycle. All the seeds had been previously sterilized with $1 \%$ sodium hypochlorite for $30 \mathrm{~min}$ and rinsed with distilled water (Yamamoto et al., 1999; Higashinakasu et al., 2004). Petri dishes and filter paper were sterilized in boiling water for $30 \mathrm{~min}$. Germinated seeds were considered those with root equal or bigger than $1 \mathrm{~cm}$ (Copeland, 1976). The significance of the effects of $B$. decubens germinating seeds on other species was tested using a Mann-Whitney U test (Siegel and Castellan-Jr, 1988).

The allelopathic effect of the aqueous leachates of $B$. decumbens green leaves, senescent leaves and roots was also tested by placing 30 seeds of $M$. minutiflora, L. sativa and P. canariensis in Petri dishes with filter paper moistened with $2 \mathrm{ml}$ of the aqueous extracts at 5, 10 and $20 \%$ (w/v). The control dishes were moistened with distilled water. The Petri dishes were then incubated in germination chambers at the same conditions as in the previous test. The percentages of germinated seeds in each Petri dish were angle-transformed prior to statistical treatment. The results of the tests using the aqueous leachates were submitted to a General Linear Model Analysis of Variance (GLM ANOVA). Significant effects were submitted to the post hoc pairwise tests of Tukey and Dunnet (Sokal and Rohlf, 2000).

\section{RESULTS}

In the presence of $B$. decumbens seeds, the germination of $L$. sativa, $P$. canariensis and $M$. minutiflora seeds decreased from $29.6 \pm 0.51,29.0$ \pm 1.26 and $29.6 \pm 0.51$ to $27.6 \pm 1.86,25.8 \pm 4.26$ and $22.3 \pm 5.16$, respectively. Although there was a general decrease in the germination, results were only significant for M. minutiflora $(\mathrm{p}<0.01)$ (mean reduction $=23 \%)$. An overall increase of the standard deviation dispersion was another noticeable effect (Fig. 1).

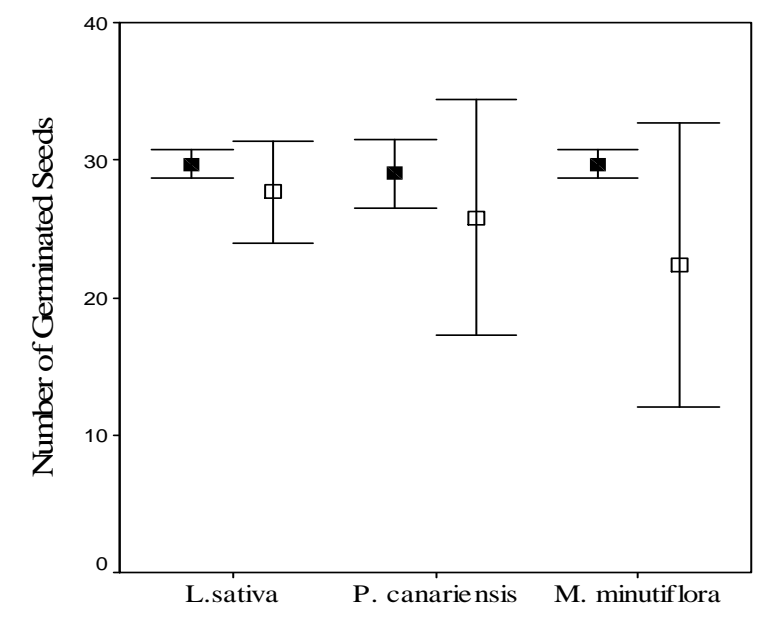

Figure1 - Mean (squares) and standard deviation (lines) from control (black squares) and experimental (empty squares) groups of Lactuca sativa (Asteraceae), Phalaris canariensis (Poaceae) and Melinis minutiflora (Poaceae) germinated seeds in the presence of Brachiaria decumbens (Poaceae) seeds.

The number of germinated seeds of the standard species ( $L$. sativa and $P$. canariensis) was reduced when exposed to the aqueous leachates of $B$. decumbens organs (green leaves, roots and senescent leaves) at different concentrations (Table 1). The inhibitory response to the aqueous 
leachates of $B$. decumbens on seed germination was more pronounced in $P$. canariensis (Table 1). However, the effects of the leachates at different concentrations were only significant against water alone (concentration 0\% versus other concentrations) (Tables 1,2) indicating that the effects were not proportional to the leachate concentration. Differential effects could not be attributed to different plant organs or to different leachate concentrations. The germination of $M$. minutiflora and $L$. sativa seeds was also significantly inhibited by the aqueous leachates of $B$. decumbens green leaves, roots and senescent leaves but only when comparing the results of distilled water and all the leachates (no proportional effect of the leachate concentration was observed) (Tables 1,2).

Table 1 - Number of Lactuca sativa (Asteraceae), Phalaris canariensis (Poaceae) and Melinis minutiflora (Poaceae) seeds germinated when in contact with the aqueous leachates of Brachiaria decumbens (Poaceae) green leaves, senescent leaves and roots, at 5, 10 and $20 \% \mathrm{w} / \mathrm{v}$ (mean of six repetitions \pm standard deviation).

\begin{tabular}{lcccc}
\hline & \multicolumn{4}{c}{ Extract concentration } \\
\hline Lactuca sativa & $\mathbf{5 \%}$ & $\mathbf{1 0 \%}$ & $\mathbf{2 0 \%}$ \\
\hline green leaves & $29.6 \pm 0.21$ & $28.6 \pm 1.21$ & $28.5 \pm 1.68$ & $28.6 \pm 1.21$ \\
roots & $29.6 \pm 0.21$ & $28.3 \pm 0.81$ & $26.5 \pm 2.25$ & $28.6 \pm 1.21$ \\
senescent & $29.6 \pm 0.21$ & $27.6 \pm 0.51$ & $28.6 \pm 1.03$ & $28.1 \pm 1.47$ \\
\hline Phalaris canariensis & & & & $19.3 \pm 1.86$ \\
green & $29.0 \pm 1.26$ & $25.0 \pm 4.04$ & $24.0 \pm 4.28$ & $21.8 \pm 4.32$ \\
roots & $29.0 \pm 1.26$ & $21.6 \pm 4.50$ & $22.0 \pm 4.93$ & $17.0 \pm 2.09$ \\
senescent & $29.0 \pm 1.26$ & $21.8 \pm 7.05$ & $20.0 \pm 7.20$ & $27.0 \pm 2.28$ \\
Melinis minutiflora & & & & $25.5 \pm 2.88$ \\
green leaves & & & & \\
roots & $29.3 \pm 0.81$ & $25.5 \pm 0.83$ & $25.6 \pm 2.16$ & $25.3 \pm 1.5$ \\
senescent & $29.3 \pm 0.81$ & $25.8 \pm 1.94$ & $25.1 \pm 2.63$ & \\
\hline
\end{tabular}

Table 2 - Results from GLM ANOVA considering the effects of aqueous leachates of Brachiaria decumbens (Poaceae) green leaves, senescent leaves and roots at different concentrations (5, 10 and 20\% w/v) on the germination of Lactuca sativa (Asteraceae), Phalaris canariensis (Poaceae) and Melinis minutiflora (Poaceae), as well as the effects of the interactions among these factors.

\begin{tabular}{lcccccc}
\hline Factor & \multicolumn{2}{c}{ L.sativa } & \multicolumn{2}{c}{$\boldsymbol{P . c a n a r i e n s i s}$} & \multicolumn{2}{c}{ M.minutiflora } \\
\hline \multirow{2}{*}{ Organ } & F & $\mathbf{p}$ & $\mathbf{F}$ & $\mathbf{p}$ & $\mathbf{F}$ & $\mathbf{p}$ \\
Leachate concentration & 1.583 & 0.214 & 1.060 & 0.353 & 0.808 & 0.451 \\
Organ X Leachate concentration & 1.328 & 0.259 & 0.607 & 0.724 & 1.843 & 0.106 \\
\hline
\end{tabular}

\section{DISCUSSION}

The results obtained here indicate possible allelopathic effects of $B$. decumbens on other species. These effects may occur at different stages of the $B$. decumbens life cycle and may come from different plant parts. During the germination stage, $B$. decumbens seeds were able to inhibit the germination of $L$ sativa, $P$. canariensis, and especially of $M$. minutiflora. Plant-to-plant interactions at the germination stage through allelopathic inhibition of root and shoot growth have been reported by Higashinakasu et al. (2004) in seven crop and weed species, and by Laterra and Bazzalo (1999) between two invasive species of the pampa grasslands (Argentina). 
Brachiaria decumbens allelopathic potential may remain throughout its lifetime including senescence, as the roots, green leaves and senescent leaves also showed allelopathic effects. Maciel et al. (2003) tested for allelopathic effects of $B$. decumbens dry leaves on the initial development of two crop legumes under agriculture conditions and obtained positive results for one of them. Indejit and Duke (2003) highlighted the advantage of the plants able to release phytochemicals from dead tissues, as their incorporation to the soil could be accelerated by leaching, thus facilitating their effects in the field.

Root exudates can be synthesized by plants and released to the soil by the live roots (Rice, 1984) and have been reported as an efficient strategy used by some Centaurea species (Bais et al., 2003, Vivanco et al., 2004) and Echinochloa crus-galli (Yamamoto et al., 1999) - plants recognized as very aggressive invaders in North America.

Testing for the allelopathic inhibition of Brachiaria species on legumes, Almeida et al. (1997) and Fagioli et al. (1997) obtained positive results using the extracts of compressed green leaves and roots of B.humidicola, B. decumbens and $B$. brizantha. The greatest effects were revealed by $B$. decumbens. However, in the compressed material the cells are smashed and all the substances inside them are released. Therefore, this procedure is far from representing the field conditions. Alternatively, aqueous leachates can represent conditions closer to the natural ones.

In the present study, the inhibition effects were stronger over the grasses (Poaceae) P. canariensis and $M$. minutiflora, especially on the latter, compared to L. sativa (Asteraceae). A number of Poaceae family species have been pointed out as carrying allelopathic activity. Four main groups of phytotoxic compounds have been identified in Poaceae - phenolic acids, hydroxamic acids, alkalois, and quinones - which can be found in all parts of the plants, from pollen to root exudates (Steinsiek, et al., 1982; Schumacher et al., 1983; Anaya et al., 1992; Einhellig and Souza, 1992; Hoffman et al., 1996; Alsaadawi et al., 1998; Kato-Noguchi and Ino, 2001; Sanchez-Moreiras, et al. 2004), and confer them a great advantage over other species.

Although the results here obtained came from a laboratory essay, they indicate the capacity of $B$. decumbens to release allelopathic substances to the environment. As in natural conditions, where a great number of interactions with the physical environment, as well as with other organisms, can enhance or restrain allelopathic effects, field experiments must be carried out to test the effectiveness of such allelopathic potential under natural conditions (Inderjit and Callaway, 2003). However, the great success of $B$. decumbens on invading cerrados could in part be due to allelopathy, as suggested in other parts of the world by authors who related allelopathy to biological invasions (Hiero and Callaway, 2003; Vivanco et al,. 2004; Ridenour and Callaway, 2001; Vaughn and Berhow, 1999).

\section{ACKNOWLEDGEMENTS}

We wish to express our gratitude to Dr. Leopoldo Magno Coutinho, who stimulated this investigation. We are also grateful to Marcelo L. Pompeo, Paulo Cesar Fernandes and Mauricio Perine for their help during field and/or lab stages. FAPESP (Fundação de Amparo à Pesquisa do Estado de São Paulo) and CNPq (Conselho Nacional de Desenvolvimento Científico e Tecnológico) provided financial support for this research.

\section{RESUMO}

Invasão biológica é uma das maiores causas atuais da perda de biodiversidade. Várias espécies que se tornam invasoras produzem substâncias fitotóxicas que aumentam sua capacidade competitiva; assim, a alelopatia é uma estratégia capaz de potencializar o sucesso de invasão. Brachiaria decumbens, uma gramínea africana, invadiu os cerrados brasileiros e representa, atualmente, uma séria ameaça à biota regional. Neste ensaio, verificamos a presença de aleloquímicos em partes de $B$. decumbens das quais poderiam ser facilmente liberados para o ambiente. Testamos a inibição da germinação de Phalaris canariensis, Lactuca sativa (espéciespadrão) e Melinis minutiflora (outra gramínea africana invasora) usando sementes de $B$. decumbens e soluções aquosas lixiviadas de suas raízes, folhas verdes e folhas senescentes, a 5, 10 e $20 \%$ de peso do material por volume de água. Tanto as sementes como as soluções lixiviadas de B. decumbens reduziram a germinação das outras espécies; a eficiência dos lixiviados aumentou de acordo com a concentração da solução. 
Acreditamos que a grande vantagem competitiva de $B$. decumbens no cerrado possa ser amplificada pela alelopatia.

\section{REFERENCES}

Almeida, A. R. P., Lucchesi, T. J. D. and Abbado, M. R. (1997), Efeito alelopático de espécies de Brachiaria Griseb. sobre algumas leguminosas forrageiras tropicais. II. Avaliações em casa de vegetação. Bol. Ind. Animal, 54, 55-64.

Alsaadawi, I. S. J., Zwain, K. H. Y. and Shahata, H. A. (1998), Allelopathic inhibition of rice by wheat residues. Allelopathy J. , 3, 185-194.

Anaya, A. L., Hernández-Bautista, B. E., JiménezEstrada, M. and Velasco-Ibarra, L. (1992), Phenylacetic acid as a phytotoxic compound of corn pollen. J. Chem.Ecol., 18, 897-905.

Bais, H. P., Vepachedu, R., Gilroy, S., Callaway, R. M. and Vivanco, J. M. (2003), Allelopathy and exotic plant invasion: from molecules and genes to species interactions. Science, 301, 1377-1380.

Brasil/ Ministério da Agricultura e Reforma Agrária (1992), Regras para análise de sementes. Brasília: Secretaria Nacional de Defesa AgropecuáriaDepartamento Nacional de Defesa Vegetal.

Callaway, R. M. (2002), The detection of neighbors by plants. /TREE/, 17, 104-105.

Castro, A. A. J. F., Martins, F. R., Tamashiro, J. Y. and Shepherd, G. J. (1999), How rich is the flora of Brazilian cerrados? Ann. Mo. Bot. Gard., 86, 192-224

Copeland, L. O. (1976), Principles of seed science and technology. Minneapolis: Burgess Publ.

Coutinho, L. M. (1978), O conceito de cerrado. Rev. Bras. Bot., 1, 17-23.

Cronk, Q. C. and Fuller, J. L. (1995), Plant invaders: the threat to natural ecosystems. London: Chapman and Hall.

D'Antonio, C. M. and Vitousek, P. M. (1992), Biological invasions by exotic grasses/fire cycle and global change. Ann. Rev. Ecol. Syst., 23, 63-87.

Einhellig, F. A. and Souza, I. F. 1992. Phytotoxicity of sorgoleone found in grain sorghum root exudates. $J$. Chem.Ecol. 18, 1-11.

Fagioli, M., Rodrigues, T. J. D., Almeida, A. R. P. and Alves, P. L. C. A. (1997), Potencial alelopático de Brachiaria decumbens e $B$. brizantha na germinação e no vigor de sementes de guandu (Cajanus cajan). Informativo ABRATES 7 (1/2).

Ferreira, A. and Aquila, M. E. A. (2000), Alelopatia: uma área emergente da ecofisiologia. Rev.Bras.Fisiol.Veg., 12, 175-204.

Filgueiras, T. S. (1990), Africanas no Brasil: Gramíneas introduzidas da África. Cad.Geociências, 5, 57-63.

Hierro, J. L. and Callaway, R. M. (2003), Allelopathy and exotic invasion. Plant and Soil, 256, 26-39.
Higashinakasu, K., Yamada, K., Shigemoru, H. and Hasegawa, K. (2004), Effects of seed exudates of several plant species during germination stage. Weed Biol.and Manage., 4, 171-175.

Hoffman, M. L., Weston, L. A., Snyder, J. C. and Regnier, E. E. (1996), Allelopathic influence of germinating seeds and seedlings of cover crops on weed species. Weed Sci., 44, 579-584.

Inderjit and Duke, S. O. (2003), Ecophysiological aspects of allelopathy. Planta, 217, 529-539.

Indejit and Callaway, R.M. (2003), Experimental designs for the study of allelopathy. Plant and Soil, 256, 1-11.

ISI/TNC (2005), The Global Invasive Species Initiative. Available in: http://tncweeds.ucdavis.edu/global. (Accessed in 26/03/2006.).

Kato-Noguchi, H. and Ino, T. (2001), Assessment of allelopathic potential of root exudate of rice seedlings. Biol. Plantarum, 44, 635-638.

Kissmann, K. G. (1997), Plantas infestantes e nocivas. São Bernado do Campo, Brazil: BASF, 2.

Klink, C. A. (1996a), Germination and seedling establishment of two native and one invading African species in the Brazilian cerrado. J. Trop.Ecol., 12, 139-47.

Klink, C. A. (1996b), Competition between the African grass Andropogon gayanus Kunth and the native cerrado grass Schizachyrium tenerum Nees. Rev.Bras.Bot., 19, 11-5.

Kolar, C. S. and Lodge, D. M. (2001), Progress in invasion biology: predicting invaders. TREE, 16, 199205.

Laterra, P. and Bazzalo, M. E. (1999), Seed-to-seed allelopathic effects between two invaders of burned Pampa grasslands. Weed Res., 39, 297-308.

Lorenzi, H. (1991), Plantas daninhas do Brasil. Nova Odessa, Brazil: Plantarum, 2.

Mack, R. N., Simberloff, D., Lonsdale, M., Evans, H., Clout, M. and Bazzaz, F. (2001), Biotic invasions: causes, epidemiology, global consequences, and control. Ecol. App., 10, 689-710.

Maciel, C. D. G., Corrêa, M. R., Alves, E., Negrisoli, E., Velini, E. D., Rodrigues, J. D., Ono, E. O. and Boaro, C. S. F. (2003), Influência do manejo de palhada de capim-braquiária (Brachiaria decumbens) sobre o desenvolvimento inicial de soja (Glycine max) e amendoim-bravo (Euphorbia heterophylla). Planta Daninha, 213, 635 - 373.

Mendonça, R. C., Felfili, J. M., Walter, B. M. T., SilvaJúnior, M. C., Rezende, A. V., Filgueiras, T. and Nogueira, P. E. (1998), Flora vascular do cerrado. In: S. Sano M. and Almeida S.P. (Orgs.) Cerrado: ambiente e flora. Planaltina, Brazil: EMBRAPACPAC, pp. 289-556.

Mittermeier, R. A.; Gil, P. R., Hoffmann, M., Pilgrim, J., Brooks, T., Mittermeier, C. G., Lamoreux, J. and Fonseca, G. A. B. (2004), Hotspots revisited. Mexico City, CEMEX. 
Myers, N., Mittermeier, R. A., Mittermeier, C. G., Fonseca, G. A. B. and Kent, J. (2000), Biodiversity hotspots for conservation priorities. Nature, 403, 853858.

Parsons, J. J. (1972), Spread of African pasture grasses to the American Tropics. J. Range.Manage., 25, 1217.

Pivello, V. R., Shida, C. N. and Meirelles, S. T. (1999a), Alien grasses in Brazilian Savannas: a threat to the biodiversity. Biodivers. Conserv., 8, 1281-1294.

Pivello, V. R., Carvalho, V. M. C., Lopes, P. F., Peccinini, A. A. and Rosso, S. (1999b), Abundance and distribution of native and invasive alien grasses in a "cerrado' (Brazilian savanna) biological reserve. Biotropica, 31, 71-82.

Rejmánek, M. and Richardson, D. M. (1996), What attributes make some plant species more invasive? Ecology, 77, 1655-1661.

Ribeiro, J. F. and Walter, B. M. T. (1998), Fitofisionomias do bioma Cerrado. In: S Sano, M. and Almeida S. P. (Orgs.) Cerrado: ambiente e flora. Planaltina, Brazil: EMBRAPA-CPAC, pp. 89-166.

Rice, E. L. (1984), Allelopathy. New York: Academic Press, 2.

Ridenour, W. M. and Callaway, R. M. (2001), The relative importance of allelopathy in interference: the effects of an invasive weed on a native bunchgrass. Oecologia, 126, 444- 450.

Sanchez-Moreiras, A. M., Weiss, O. A. and ReigosaRoger, M. J. (2004), Allelopathic evidence in the Poaceae. Bot.Rev., 69, 300-319.

Schumacher, W. J., Thill, D. C. and Lee, G. A. (1983), Allelopathic potential of wild oat (Avena fatua) on spring wheat (Triticum aestivum) growth. J. Chem.Ecol., 9, 1235-1245.

Siegel, S. and Castellan-Jr., N. J. (1988), Nonparametric statistics for behavioral sciences. New York: McGraw-Hill, 2.

Sokal. S. S. and Rohlf, F. J. (2000) Biometry. New York: W H Freeman.
Steinsiek, J. W., Oliver, L. and Collins, F. C. (1982), Allelopathic potential of wheat (Triticum aestivum) straw on selected weed species. Weed Sci., 30, 495497.

Vaughn, S. F. and Berhow, M. A. (1999), Allelochemicals isolated from tissues of invasive weed garliz mustard (Allaria petiolata). J. Chem. Ecol., 25, 2495-2504.

Vitousek, P. M., D’Antonio, C. M., Loope L. L., Réjmanek, M. and Westbrooks, R. (1997), Introduced species: a significant component of human-caused global change. New Zealand J. Ecol., 21, 1-16.

Vivanco, J. M., Bais, H. P., Stermitz, F. R., Thelen, G. C. and Callaway, R. M. (2004), Biogeographical variation in community response to root allelochemistry: novel weapons and exotic invasion. Ecol. Lett., 7, 285-292.

Williamson, M. (1996), Biological Invasions. London: Chapman and Hall.

Wilcove, D. S., Rothstein, D., Dubow, J., Phillips, A. and Losos, E. (1998), Quantifying threats to imperiled species in the Unites States. Bioscience, 48, 607-615.

Whittaker, R. H. and Feeney, P. P. (1971), Allelochemicals - chemical interactions between species. Science, 171, 757-770.

Yamamoto, T., Tomita, K. Y., Kosemura, S., Yamamura, S., Yamada, K. and Hasegawa, K. (1999), Allelopathic substance exuded from a serious weed, germinating barnyard grass (Echinochloa crusgalli L.), roots. J. Plant Growth Regul., 18, 65-67.

Received: May 18, 2006; Revised: December 26, 2007; Accepted: March 13, 2008. 